JURNAL PENDIDIKAN, p-ISSN 2715-095X, e-ISSN 2686-5041

Volume 30, No.2, Juli 2021 (187-198)

Online: http://journal.univetbantara.ac.id/index.php/ip

\title{
Perlu Kehati-hatian Dalam Pemberian Materi Pendidikan di Indonesia
}

\section{Djaja Hendra}

\author{
Universitas Widya Mataram Yogyakarta, E-mail: djajahendra01@gmail.com
}

Received: March 9, 2021

Accepted: April 24, 2021

Online Published: Juni 26, 2021

\begin{abstract}
Abstrak: Dunia pendidikan dan dunia kerja sering tidak bersesuaian di Indonesia. Akibatnya, pengangguran pun semakin menjadi-jadi. Nampak, berbagai kebijakan telah dilakukan oleh pemerintah tetapi masalah pendidikan tidak pernah tuntas. Belum lagi kondisi daerah yang terserak. Kurikulum nasional, sebagai pedoman, sudah diberikan dan berharap kualitas hasil dapat seragam.Tetapi kenyataan, kurikulum harusnya dipahami tidak kaku dan disesuaikan dengan kondisi daerah, sayangnya, terjadi sebaliknya. Tenaga pengajar dari Jawa lebih responsif, cepat dan informatif ketimbang rekan mereka di luar Jawa. Di sini hendaknya materi pendidikan jangan melulu bersandar pada kurikulum nasional belaka. Jika tidak, pengajar luar Jawa akan selalu tertinggal. Dalam dua dasawarsa terakhir, mereka yang berasal dari Jawa dalam tes ASN mengikuti tes ASN di luar Jawa. Meski berjauhan dengan sanak-saudara, jika diterima, sekaligus menunjuk tingkat persaingan dan lapangan kerja di Jawa begitu padat sehingga memaksa untuk keluar. Terpenting mereka kerja. Untuk mengantisipasi materi-materi tes ditambah dengan muatan lokal sesuai daerah sehingga sulit diketahui peserta tes dari Jawa dan itu sah-sah saja dalam rangka pemerataan antardearah.
\end{abstract}

Kata-kata kunci: materipendidikan, tes-ASN, kurikulum, pengajar, daerah luar Jawa

\section{Care is Needed in Providing Educational Materials in Indonesia}

\section{Djaja Hendra}

\author{
Universitas Widya Mataram Yogyakarta,E-mail: djajahendra01@gmail.com
}

\begin{abstract}
The world of education and the world of work are often incompatible in Indonesia. As a result, unemployment has become increasingly rampant. It seems that various policies have been carried out by the government but the problem of education has never been resolved. Not to mention the condition of the scattered areas. National curriculum, as a guideline, have been given and hope that the quality of the results can be uniform. But in reality, the curriculum should be understood not to be rigid and adapted to local conditions, unfortunately, the opposite happened. The teaching staff from Java is more responsive, fast and informative than their counterparts outside Java. Here the educational material should not rely solely on the national curriculum. If not, the outer Java teachers will always be left behind. In the last two decades, those who came from Java in the ASN test have taken the ASN test outside Java. Even though he is far from his relatives, if accepted, he will at times point out the level of competition and employment in Java is so dense that it forces him to leave. Most importantly they work. To anticipate that the test materials are added with local content according to the region so that it is difficult to know the test takers from Java and that is fine in the context of equal distribution between directions.
\end{abstract}

Keywords: educational materials, ASN-test, curriculum, teachers, areas outside Java

\section{Pendahuluan}


Paling tidak, sudah lebih dari dua dasawarsa terakhir persoalan pemberian materi pendidikan di semua jenjang pendidikan mulai dipertanyakan. Soalnya, pendidikan nampaknya tidak lagi sebagai satu-satunya yang bisa menaikkan status, harkat dan martabat sosial seseorang. Pen-didikan, dalam persepsi seseorang mulai luntur ke arah yang biasabiasa saja, sama seperti pekerjaan profesional lain. Lebih tidak nyaman lagi bilamana ada yang mengatakan: 'Buat apa sekolah tinggi-tinggi jika nantinya sulit untuk mendapatkan pekerjaan alias nganggur (Seran, S: 2017). Bahkan, mungkin dikhawatirkan ada penelitian yang menyimpulkan, 'semakin tinggi pendidikan seseorang maka semakin sulit untuk mendapatkan pekerjaan'. Sehingga dengan pendidikan diasumsikan sekadar 'memperpanjang usia dan waktu saja agar tidak disebut sebagai pengangguran'. Lebih memprihatinkan lagi jika seseorang itu telah menamatkan pendidikan dari sekolah menengah atau bahkan perguruan tinggi! Mereka jika dilihat dari sisi usia jelas sudah bukan remaja dan jika dilihat dari sisi beban dan tanggung-jawab masih tergantung sama orangtua. Apa kita tidak linglung dan serba-salah? Masih untung jika orangtua mau mengerti dan menerima kondisi kita sekarang yang serba sulit ini. Tetapi jika tidak! Sulit untuk dibayangkan apa yang mungkin akan terjadi? Kegelisahan semacam ini semakin menjadi-jadi setelah masa pandemi menerjang negara kita awal tahun 2020 lalu; yang hingga menjelang pertengahan tahun 2021 belum lagi menunjukkan tanda-tanda bakal mereda; malah jika mencermati semua media elektronik, semakin ganas (angkanya saja sudah menebus 1.5 juta lebih orang yang terpapar). Dengan kondisi semacam ini, mereka yang sudah mendapatkan pekerjaan pun di PHK; atau bekerja sift-siftan; atau pengurangan jam kerja; dan berbagai strategi lain dari perusahaan agar tidak mem-PHK karyawannya. Semua itu berlangsung dengan cara terpaksa karena keadaan. Masalah seperti ini tidak saja terjadi Indonesia tetapi juga di seluruh dunia. Jika pun terjadi pemulihan ekonomi, rasanya, tidak serta-merta lapangan kerja akan siap menerima karyawan baru atau karyawan lama untuk kembali lagi bekerja dalam tahun-tahun berikutnya.

Mungkin dalam kaitan pemberian materi pendidikan di dunia pendidikan ini secara sengaja dimasalahkan, paling tidak, sebagai salah satu penyebab tidak terakomodirnya seseorang dalam lapangan pekerjaan (Lia dkk, 2017). Bukti tersebut bukan isapan jempol, omong kosong atau asal bicara saja. Ada berapa banyak orang keluar dari profesinya (apa yang ditimba di sekolah dan apa yang terjadi di lapangan bisa berbeda) bahkan tidak ada hubungan sama sekali dengan pertumbuhan ekonomi negara. Pekerjaan yang dilakukan, bisa jadi, tidak dikerjakan oleh orang-orang yang berpendidikan sama sekali. Asalkan seseorang itu dapat membaca-menulis maka pekerjaan-pekerjaan tersebut dapat dilakukan. Atau, pekerjaan yang sedianya dilakukan oleh orang yang hanya bisa baca-tulis dikerjakan oleh mereka yang berpendidikan. Kondisi demikian bukan barang baru, hal itu telah berlangsung lama dan telah menjadi pemandangan biasa dalam kehidupan sehari-hari (bagi sementara pihak tentu ada hubungan). Hal ini menunjukkan tidak adanya keterkaitan itu (Mungkin ini contoh saja. Dalam Penelitian Kebidanan, 'Pendidikan Ibu-ibu hamil berpendidikan rata-rata SD yaitu ada 14 orang dari 50 orang responden. Selebihnya tidak berpendidikan/tidak sekolah. Penelitian ini memang terbukti karena pendidikan formal 14 orang ibu hamil ini betul-betul mengetahui tentang pengetahuan kesehatan sang bayi. Sisa 36 orang responden itu kita harus hati-hati menyimpulkannya. Betul bahwa pendidikan 
formal mereka dianggap kurang. Jika betul kebenaran itu yang kita pegang lantas 36 orang responden ini bayinya dianggap kurang baik kesehatannya. Puspaningrum, Nofemi; Catur Styorini: 2014). Tidak perduli seseorang itu, dulu, sekolahnya mendapatkan ranking terbaik di kelas atau tidak, sama saja. Kejadian ini hendaknya menjadi bahan koreksi (instropeksi) terkait kurikulum yang kita berikan kepada anak-didik selama ini. Ahli pendidikan mengira, mungkin disebabkan karena sumber daya manusianya seperti guru, dosen dan tenaga pendidikan lainnya yang kurang berkualitas (Kurjono, B, M, 2021; Hadi, M, 2021; Utami, S, 2009); juga mungkin ada yang melihat dari sisi sarana dan prasarana kurang memadai (Hartanto, I, G, 2017; Huda, M, N, 2018); mungkin ada yang melihat dari sisi pedagoginya kurang memenuhi persyaratan (Fhatoni, B, 2020; Kasirah, I, 2014); mungkin ada yang melihat dari skala makronya berupa sistem ekonomi negara yang kurang baik (Killian, P.M, E, 2012; Nurhadi, 2018); mungkin ada yang melihat sebagai konsekuensi dari Negara Sedang Berkembang (Nugraheni, S, 1997) dll. Berbagai usaha pun telah pula dilakukan. Berganti-ganti menteri (Pendidikan dan Kebudayaan pun) sebenarnya dihadapi yang itu-itu saja. Sekolah-sekolah dengan ketrampilan tertentu; sekolah-sekolah dengan bidang-bidang khusus dan yang tidak; bisa diselenggarakan oleh sekolah-sekolah formal. Misalnya, dibuatkan sekolah-sekolah yang hampir mirip dengan sekolah in-formal juga telah dilakukan dan lain sebagainya. Hasilnya, sama saja.

Nampak, sudah diupayakan semuanya, tetapi persoalan pendidikan tetap selalu menjadi PR (Pekerjaan Rumah) besar dan kompleks bagi kita semua. Setiap lulusan di berbagai jenjang pendidikan dipastikan tidak seluruhnya terserap di dunia kerja. Padahal dunia pendidikan adalah sarana utama untuk sampai kepada dunia kerja. Kelulusan mereka pada tahun ini saja akan bertambah bersama dengan tahun lalu, berkumpul bersama dengan tahun-tahun sebelumnya, begitu seterusnya. Kumulatif ini terakumulasi hingga memperpanjang jarak (waktu) pengang-guran dan menambah penggangguran dari tahun ke tahun. Dunia kerja dengan dunia pendidikan seolah-olah berjalan sendiri-sendiri. Coba kita simak data BPS (2020) ini saja -- belum termasuk pengangguran mendadak masa pandemi virus corona-19 - bahwa, angkatan kerja pada bulan Februari 2020 sebanyak 137.91 juta orang, naik 1.73 juta orang dibanding bulan Februari 2019. Berbeda dengan naiknya jumlah angkatan kerja yaitu Tingkat Partisipasi Angkatan Kerja (TPAK) turun sebesar 0.15 persen poin. Mungkin dengan perubahan ini (kita sedikit menarik napas lega) bahwa dengan tingkat partipasi aktif yang agak menurun itu, kita tetap harus berhati-hati pula dalam melihatnya. Bila dimaksud, mereka semua telah terserap di dunia kerja maka kita patut bergembira. Tetapi mungkin, karena bosan tidak diterima-terima dalam dunia kerja sehingga tidak mau lagi untuk melamar pekerjaan; ini sungguh mengenaskan, ironis dan mungkin pula sangat memprihatinkan. Hal yang kedua inilah yang lebih mungkin terjadi. Seperti kita lihat dalam setahun terakhir, pengangguran bertambah 60 ribu orang, berbeda dengan TPT yang turun menjadi 4.99 persen bulan Februari 2020. Dilihat dari tingkat pendidikan, TPT Sekolah Menengah Kejuruan (SMK) memang masih yang paling tinggi di antara tingkat pendidikan lain, yaitu sebesar 8.49 persen. Bagaimana dengan perguruan tinggi, sekolah menengah baik pertama dan atas, belum lagi sekolah dasar dan taman kanak-kanak? Tentu tak terkirakan jumlahnya. Ingat! Jumlah tersebut belum termasuk mereka yang tidak terdaftar atau mereka yang bergerak di sektor-sektor in-formal dan nonformal lainnya; yang biasa disebut sebagai pengangguran tersembunyi itu.

Sebenarnya, kita patut berbangga karena penduduk yang bekerja sebanyak 131.03 juta orang atau bertambah sebanyak 1.67 juta orang dari bulan Februari 2019. Dengan lapangan pekerjaan yang mengalami peningkatan persentase terutama Jasa Pendidikan 
(0.24 persen poin), Kon-struksi (0.19 persen poin) dan Jasa Kesehatan (0.13 persen poin). Sementara lapangan pekerjaan yang mengalami penurunan terutama di sektor-sektor tradisional seperti pada Pertanian (0.42 persen poin), Perdagangan ( 0.29 persen poin) dan Jasa Lainnya (0.21 persen poin). Hal ini menunjukkan adanya kreativitas dan inovasi dari anak bangsa terhadap sektor-sektor modern ketimbang sektor-sektor tradisional. Atau bisa jadi, pencari kerja tidak memprioritaskan sektor tradisional dalam benaknya. Sebanyak 74.04 juta orang (56.50 persen) bekerja pada kegiatan in-formal. Selama setahun terakhir (bulan Februari 2019-bulan Februari 2020), persentase pekerja formal meningkat sebesar 0.77 persen poin. Persentase tertinggi pekerja pada bulan Februari 2020 adalah pekerja penuh (jam kerja minimal 35 jam per minggu) sebesar 69.90 persen. Sementara itu, pekerja tidak penuh terbagi menjadi dua, yaitu pekerja paruh waktu (23.74 persen) dan pekerja setengah penganggur (6.36 persen). Dalam setahun terakhir, persentase pekerja setengah penganggur turun sebesar 1.01 persen poin, sedangkan persentase pekerja paruh waktu meningkat sebesar 1.07 persen poin.

Perlu diingat bahwa data BPS (2020) ini diduga dikumpulkan sekitar 1 sampai 1.5 bulan sebelum masa pandemi/covid-19. Jadi berdasarkan data, pengangguran pun sudah sangat banyak terjadi di negeri kita. Di masa pandemi lebih sulit lagi dalam menghitung jumlah pengangguran-nya. Pada masa ini hampir pasti setiap perusahaan, hotel-hotel, rumah makan, tempat-tempat wisata dll ada yang langsung melakukan PHK (Pemutusan Hubungan Kerja) terhadap karyawannya maupun mereka yang gulung-tikar. Malah, bisa jadi, pemilik perusahaan dll itu mensyukuri dengan adanya pandemi karena tidak perlu repot-repot melakukan pemecatan/ pemberhentian (karyawan yang bandel, bolos, kelebihan karyawan d1l); yang kelihatan tidak manusiawi itu. Tetapi ada pula yang cukup manusiawi, seperti ada yang menjadwal-ulang kerja karyawan misalnya dengan sift-siftan; ada pula yang bekerja dengan waktu kerja tidak satu hari penuh; atau ada yang mensiasati jadwal dalam satu minggu dengan 3 hari kerja dll. Tetapi ada pula dari mereka yang lebih fatal yakni dengan pengurangan karyawan dan pemotongan gaji. Untuk pemotongan gaji tidak mendapat $100 \%$ tetapi memperoleh hanya separohnya saja. Atau, mereka diistirahatkan di rumah ssambil menunggu kerja lagi yang entah sampai kapan tanpa ada kejelasan. Begitu seterusnya. Namun apapun alasannya pengangguran tetap makin bertambah.

\section{Kehati-hatian Dalam Pemberian Materi Pendidikan}

Lama sudah pemberian materi pendidikan (dalam proses belajar-mengajar) bergayut dalam pikiran parapengajar di semua jenjang manapun di negeri ini. Kalau ingin jujur, persoalan demikian sudah menjadi materi ikutan di setiap jenjang pendidikan (Yasir, S. N. Hasanah, 2018). Kekhawatiran dipecat, dipindah-tugaskan, tidak disenangi oleh rekanrekan sejawat, di-non-job-kan dll merupakan bagian dari kebijakan pendidikan itu sendiri. Memilih diam, tak acuh atau cuek, atau lurus sesuai kurikulum dlsbg merupakan bagian pilihan yang paling rasional, masuk-akal dan aman menurut versi parapengajar masingmasing. Paling tidak, untuk menghibur diri; toh peserta didik akan meninggalkan institusi sekolah secara alamiah cepat atau lambat. Tidak akan mungkin peserta didik terus bercokol di sekolah yang sama betapa pun bodohnya dia. Peserta didik pasti meninggalkan sekolah untuk menjadi alumni, entah berhasil menamatkan maupun hal-hal lain. Tentu, jika 
dibiarkan dan diberikan sepenuhnya kepada parapengajar, selain berpotensi dapat ke luar dari jalur kurikulum; khawatir karena ketersebaran daerah yang tidak merata membawa konsekuensi kebijakan-kebijakan pemerintah termasuk kurikulum akan menjadi bias. Belum lagi kualitas masing-masing parapengajar yang berbeda maupun sarana dan prasarana pendukung pendidikan yang kurang memadai membuat pendidikan di Indonesia semakin timpang. Kita jangan berharap jika pendidikan di Jakarta bakalan sama dengan mereka yang berada di Jayapura atau di pulau Rote sana. Bandingkan pula Kota Bandung dengan Kota Pendidikan Yogyakarta, pasti berbeda pula. Mungkin, rekruitmen ASN (Aparat Sipil Negara) sama di seluruh Indonesia misalnya, tetapi kualitas yang diterima pun pasti berbeda. Kita bisa saksikan sistem rekruitmen pegawai untuk Luar Jawa sebagai misal, pasti dipenuhi peserta dari Jawa saat ini, dengan melihat satu atau dua hari menjelang tes ASN Luar Jawa. Pesawat terbang, kapal-laut, transport-tasi darat penuh berisi peserta tes ASN dari Jawa. Hal ini, jika dibiarkan terus berlarut-larut tentu akan diisi oleh ASN berasal dari Jawa semata untuk pegawai di daerah (Luar Jawa). Mereka jelas jauh lebih pintar, terbuka dan terampil serta informatif ketimbang pegawai di daerah.

Dengan kualitas seperti ini, pegawai yang berasal dari Jawa akhirnya akan mendominasi pegawai Luar Jawa. Pegawai yang bertempat tinggal (berasal) dari Luar Jawa akan menjadi penonton di daerah asal mereka sendiri. Padahal pegawai asal Jawa, sebenarnya tamu (pendatang) tetapi malah mereka sebagai tuan-rumah di bukan tanah kelahiran mereka. Jika dilihat dari sisi transmigrasi, mungkin pemerintah tak perlu bersusah-susah mempersiapkan lahan dan mengeluarkan dana maupun prasarana lainnya. Cukup ikut sebagai peserta tes ASN (dari Jawa) saja, urusan selesai. Mereka telah bertransmigrasi dengan sendirinya ke Luar Jawa. Tetapi bukan itu yang kita harapkan. Ini persoalan keadilan dan pemerataan antardaerah di Indonesia. Itulah sebabnya, materi pendidikan hendaknya dilakukan berbeda dengan di Jawa. Pasti dan harus, kurikulum memang harus disesuaikan dengan kurikulum nasional; sehingga menunjukkan tidak adanya perbedaan atau setidak-tidaknya nyaris sama; seperti kebijakan yang telah kita jalankan selama ini. Tetapi di luar kurikulum, harusnya dilakukan dengan cara-cara berbeda. Seperti contoh tes ASN (lebih terstruktur) tadi. Materi kebijakan pemerintah bagi setiap peserta tes yang baru lulus/tamat tentu akan sama. Jelas, mereka akan mengalami kesulitan dalam menjawab tes ASN dibanding dengan pegawai yang sudah lama magang. Meski soal seperti ini tidak banyak tetapi cukup mengganggu bagi mareka yang baru lulus. Tetapi jika peserta tesnya cukup cerdas, tentu soal-soal sesuai kurikulum dijawab dengan baik dan benar. Untuk memberikan kemung-kinan peserta tes ASN Luar Jawa, mereka harusnya diberi materi muatan lokal sehingga mereka yang berasal dari Jawa agak kesulitan dalam menjawab. Kecuali bagi pegawai dari Jawa yang telah terlebih dahulu magang/honorer di dareah yang bersangkutan. Meski materinya tidak terlalu banyak tidak bakal mengganggu mereka yang memang cerdas (dari Jawa). Jika tidak demikian, tentu apa yang kita khawatirkan masih akan terus terjadi. Sekarang saja karena sulitnya mendapatkan pekerjaan orang lebih rela untuk bekerja di Luar Jawa, berjauhan dengan keluarga dan pendapatan yang tidak seberapa itu ketimbang menjadi pengangguran di Jawa.

Tanpa mengurangi sisi pedagogi seperti aspek koqnitif lebih banyak diberikan untuk sekolah-sekolah yang bersifat umum ketimbang aspek afektif dan aspek psikomotoriknya. Demikian pula aspek psikomotorik untuk sekolah-sekolah yang bersifat kejuruan harusnya diperbesar daripada aspek koqnitif maupun aspek afektifnya (http//p3ai.polsri.ac.id). Selama ini, bagi parapengajar ternyata tidak mudah untuk membedakan apalagi sampai mengaplikasikannya di masyarakat. Memang porsi tersebut sudah sesuai dengan apa yang 
diatur dalam peraturan Menteri Pendidikan dan Kebudayaan kita. Tapi apa yang diberikan, mau tidak mau, harus meningkatkan kualitas porsi pada masing-masing sekolah. Jadi, masing-masing materi dikreatifkan dan diinovatifkan oleh parapengajar sendiri (Widyamingrum, H, S: 2021). Cuma parapengajar, bisa jadi, tak dapat membedakan seberapa besar porsi untuk aspek koqnitif dan seberapa besar pula untuk aspek psikomotorik bagi sekolah-sekolah kejuruan maupun umum dari aspek-aspek yang sudah ada sebelumnya; sehingga tidak saling bertabrakan. Perlu kehati-hatian agar kekhawatiran tabrakan antarberagam jenis sekolah tidak terjadi, mengingat porsi-porsi tersebut sudah ada di masing-masing sekolah, tinggal secara kreatif dan inovatif bagaimana parapengajar menempatkan aspek-aspek tersebut sesuai dengan porsinya. Sekolah-sekolah yang bersifat kejuruan tidak jumbu dengan sekolah-sekolah yang bersifat umum. Dalam banyak kasus, parapengajar tidak dapat membedakan aspek-aspek mana dimaksud. Apa yang mereka lakukan adalah membabi-buta, menabrak rambu-rambu sana-sini tanpa mempertimbangkan peserta didiknya, kesiapan sarana-prasarana; dan lebih celaka lagi mana porsi untuk sekolah kejuruan dan mana porsi untuk sekolah umum. Kalau kita telah terbiasa membedakan itu maka dengan sangat mudah pula dilakukan tanpa perlu menabrak. Demikian pula untuk pendidikan tinggi berlaku sama saja. Pastinya akan kesulitan dalam melakukan perubahanperubahan jika sikap dan perilaku parapengajar kita masih seperti sekarang ini.

Pemberian materi pendidikan demikian, diakui tidak terlalu mudah memang. Kebiasaan untuk menyesuaikan dengan kurikulum nasional telah berhasil mendorong setiap parapengajar berbuat seperti itu. Tidak itu saja. Pada tingkat sekolah menengah pertama dan menengah atas dilakukan demikian, tidak terkecuali perguruan tinggi. Di perguruan tinggi mungkin tidak terlalu ketat sebagaimana yang terjadi di sekolah-sekolah menengah pertama dan menengah atas, tetapi hakekatnya sama saja. Adanya ketentuan untuk memasukkan matakuliah-matakuliah tertentu terutama dalam hakekat berbangsa dan negara; menyesuaikan pula dengan program studi-program studi. Ini menunjukkan kesamaan dan secara berkala Dirjen Dikti akan mengevaluasi matakuliah-matakuliah yang diajarkan sembari melakukan perubahan-perubahan di sana-sini sesuai perkembangan zaman. Itu baru matakuliah-matakuliah belum lagi yang lain. Lantas, bagaimana dengan sarana dan prasarana serta jumlah mahasiswa? Sama saja. Ada pengaturan-pengaturan juga dari pusat. Beranikah perguruan tinggi baik swasta maupun negeri untuk menolaknya? Tidak pernah ada yang berani. Mungkin pihak pusat 'tidak terlalu menekan' perguruan tinggi-perguruan tinggi yang berani menolak, tetapi evaluasi secara berkala terus dilakukan, samalah artinya dengan 'mengawasi' perguruan tinggi-perguruan tinggi tersebut. Bentuk paling ekstrim sebagai pengawasan adalah penurunan status, tidak diberi daftar kebijakan-kebijakan pemerintah dll. Semula berstatus ujian sendiri, dapat berubah pengujinya oleh Dikti sendiri. Atau, sarana dan prasarana yang diberikan secara cuma-cuma dalam rangka 'pembinaan' bisa berubah yaitu dilakukan dengan cara membeli dll. Dengan langkah-langkah yang dilakukan pemerintah seperti itu, mana ada mahasiswa yang berani masuk ke perguruan tinggi-perguruan tinggi seperti itu? Bukankah keberlangsungan hidup perguruan tinggi sebagian besar dari kontribusi SPP mahasiswa! (lihat, salah satu bentuk 'pengawasan' dari Dirjen Pendidikan Tinggi tahun 2021).

Pastinya, pemberian materi dengan aspek-aspek kognitif dan psikomorik disesuaikan dengan kondisi daerahnya masing-masing. Artinya, penduduk setempat sangat 
mengetahui akan kondisi daerahnya itu dan menjadi tidak mudah untuk diketahui dari orang-orang di Jawa jika mereka berniat ke daerah, manakala baru pertama kali ke daerah itu dan hanya dalam durasi waktu satu-dua hari saja. Materi lokal atau muatan lokal menjadi senjata ampuh untuk membedakan mereka yang berasal dari daerah itu atau bukan. Secara tidak langsung, dengan sendirinya mampu mendiskriminasikan melalui muatanmuatan lokal tanpa harus kita sosialisasikan. Soalnya, jika hal demikian diinformasikan kepada khalayak maka kita dianggap betul-betul diskriminatif. Padahal kita tidak punya maksud demikian untuk sampai ke sana, melainkan memberi kesempatan kepada putra daerah-putra daerah menikmati kondisi yang sama dengan pusat.

\section{Apakah Kita Siap?}

Tentu pertanyaan yang dilontarkan ini sulit untuk dijawab seketika, apakah kita siap atau tidak? Sebagai contoh, apakah kita begitu yakin bahwa peraturan (baik kebijakan dan sarana pendukung kebijakan) tingkat bawah hingga luar daerah akan jauh dari penyimpangan? Ini persoalan mental manusianya. Bukan soal jarak dari pusat pemerintahan! Kita sudah memiliki inspektorat di semua jenjang, membentuk KPK, pengawasan dan pengontrolan dari masyarakat sipil dan lain-lain; apakah itu semua tidak cukup! Walaupun tempat/daerah cukup jauh dari pusat pemerin-tahan, apakah kita berani menjamin tidak terjadi penyimpangan? Calon bupati terpilih saja bisa lolos skrining kewarganegaraan, dia orang AS atau Indonesia! Kebiasaan dan sikap parape-ngajar dan peraturan-peraturan yang ditetapkan, tentu dibuat sudah dipertimbangkan sebelumnya dengan matang. Padahal kebijakan itu semua bukan harga mati yang tidak bisa dirubahrubah. Sudah tentu jika ada kesalahan atau ketidaktepatan dan lain-lain tentu dilakukan penyempurnaan-penyempurnaan di sana-sini. Perubahan digunakan agar dapat mengantisipasi perubahan zaman maupun perkembangan teknologi dlsbnya. Sebagai contoh. Perubahan kurikulum jenjang pen-didikan Sekolah Lanjutan Tingkat Atas, kurikulum yang digunakan sekarang pun sebenarnya merupakan hasil dari perubahanperubahan kurikulum sebelumnya. Demikian pula untuk jenjang pendidikan Sekolah Lanjutan Tingkat Pertama maupun Madrasah Aliyah dan seterusnya ke bawah. Jenjang pendidikan tinggi pun sama, pasti berubah. Jika perubahan-perubahan utamanya adalah untuk menyesuaikan dengan perubahan zaman dan teknologi maka untuk pemerintah masih ditambah lagi dengan sebaran pendidikan yang tidak merata di semua jenjang dan tingkat pendidikan. Belum lagi jika kita pertanyakan kualitas sarana dan prasarana, parapengajar, kebijakan, sekolah yang dikelola swasta dll, begitu rumitnya dan diharapkan output/hasil akan sama sesuai standar sehingga makin tidak mudah. Tetapi perbedaan-perbedaan itu mau sampai kapan? Sebagai bukti. Sekolah-sekolah yang berada di Jakarta tentu tidak bakal sama kualitasnya dengan parapengajar yang berada di Sulawasi Utara sana. Demikian pula daya responsif siswanya pun pasti berbeda pula. Jauh lebih percaya diri siswa yang berasal dari Jakarta ketimbang siswa yang berada di Sulawasi Utara. Hanya mungkin karena kurikulumnya sama, umumnya kualitas mereka di Sulawasi Utara sana akan sedikit lebih baik? Tetapi cobalah jika soalnya berkaitan dengan perkembangan teknologi, tentu di Luar Jakarta terutama di pelosok-pelosok daerah akan kesulitan dalam pengerjaan soalnya.

Belum lagi kebiasaan-kebiasaan dan sikap parapengajar dalam menginterpretasikan kurikulum yang sudah diatur (berupa kebijakan teknis/juknis), hampir pasti mempunyai sikap dan kebiasaan yang sama (ini yang diharapkan pemerintah) pula untuk merubah sesuai dengan kreativitas dan inovasi parapengajar sendiri, tentu menjadi tidak mudah dan 
tidak mungkin terlaksana dengan baik. Pemerintah selalu berharap, memang ada keseragaman dalam memahami kurikulum yang diberikan; sehingga kreativitas dan inovasi parapengajar yang muncul seketika, dapat menjadi sia-sia belaka. Walaupun harus kita akui pula bahwa, mungkin ada satu-dua peserta didik dengan kualitas baik berasal dari pelosok daerah, tetapi tidak sebanyak mereka yang berada di Pusat Pemerintahan. Mereka yang lebih baik pun umumnya bukan berasal dari sekolah-sekolah yang memang secara struktur dipersiapkan. Tetapi mereka umumnya berasal dari kualitas pribadi masing-masing dan dukungan lingkungan keluarga; sehingga sekolah-sekolah tinggal memfasilitasi saja. Kemampuan pribadi dapat dinilai berubah menjadi kemam-puan kelembagaan sekolah di mana peserta didik tersebut bersekolah. Ini memang dapat kita katakan sebagai kekecualian. Kebijakan-kebijakan pemerintah yang tegas dan mungkin juga kaku, memang memberanguskan kreativitas dan inovasi itu sendiri; sehingga bagaimana mung-kin kita berharap lebih dari mereka yang berasal dari daerah (Luar Jawa)? Parapengajar tentu akan memilih tindakan yang tidak kreatif dan inovatif manakala bisa mengancam karir dan reputasi mereka di kemudian hari. Pastinya keberlangsungan kehidupan sehari-hari lebih diuta-makan di masa-masa sekarang ketimbang idealisme yang kosong. Buat apa mulukmuluk dan berprestasi baik jika nantinya kepangkatan dan jabatan mereka menjadi terhambat, mandek dan terlunta-lunta. Sudah sangat banyak kasus dari orang-orang yang ada, baik yang berada di birokrasi maupun parapengajar yang gagal memperjuangkan hakhak dan karir mereka, bahkan sampai diurus ke Pusat Pemerintahan segala. Hasilnya, nol alias sia-sia. Pernah ada, sebagai contoh saja walau sudah lama kejadiannya tetapi memberikan pelajaran yang cukup baik zaman Presiden Soeharto, seorang dosen, lulus P4 bahkan beragam prestasi yang mumpuni. Satu di antara kelulusan itu ada yang berasal dari BP7 Pusat. Menurut kabar-kabur, seseorang yang lulus dari BP7 Pusat akan mendapatkan karpet merah ke mana pun yang dia kehendaki (tempat kerja) termasuk pindah kerja, naik jabatan dan lain-lain. Orang lain pun akan mengatakan demikian. Di zaman Presiden Soeharto lagi! Pada saat itu, di instansi tujuan-tempat kerja dosen tersebut mengajar sebenarnya sudah sebagai dosen yayasan. Tinggal menunggu diangkat sebagai dosen (PNS) Pegawai Negeri Sipil. Jadi ke lulusan dari BP7 Pusat sebagai tambahan persyaratan belaka. Namun apa yang terjadi? Untuk diangkat sebagai PNS dia harus lulus ujian yang diselenggarakan oleh pemerintah. Kenyataan, dia tidak lulus. Dengan membawa bukti berbagai per-syaratan termasuk kelulusan penataran P4 dari BP7 Pusat maka diuruslah ketidak-lulusan tersebut dari instansi tempat dia bekerja itu sampai ke Pusat/Jakarta. Berhari-hari dosen tersebut mengurus segala adminstrasi dan tetek-bengek lain selama berada di Jakarta. Tetapi hasilnya tetap saja nihil. Akhirnya, dosen tersebut dengan sangat terpaksa dikeluarkan dari tempat kerja dia mengajar.

Menyimak kasus ini, memang akhirnya, kurikulumlah yang menentukan dan seolah-olah sebagai harga mati. Oleh karena itu, tidak ada jalan lain kecuali kita harus menyikapi dengan bijak dan tetap mengedepankan kurikulum berskala nasional yang telah ditetapkan itu. Ketun-tasan kurikulum memang menuntut parapengajar harus pawai dan cerdas. Tetapi bagi para-pengajar yang kualitasnya biasa-biasa saja, tentu harus dipikirkan ulang (biasanya mereka yang cerdas sangat jarang memilih profesi sebagai guru/parapengajar). Inilah persoalan (tidak) baru dan menjadi tidak mudah dicari jalankeluarnya. Umumnya parapengajar yang sudah mengikuti dan menyesuaikan dengan 
kurikulum yang ditetapkan maka sudah dianggap selesai tugas dan tanggung jawab sebagai pengajar. Memang, akhirnya mereka tidak terlalu berani berkreasi dan berinovasi. Apalagi mereka yang berada di pelosok daerah yang jaraknya cukup jauh dari pusat ibukota provinsi, kabupatan/kota maupun kecamatan. Di sini, terkadang kurikulum nasional seperti layaknya berhala saja dan tidak bisa diganggu-gugat. Sehingga pertanyaannya, siapkah kita? Jawabnya, sampai kapan pun kita tidak akan pernah siap dalam arti yang sebenarnya. Siap dalam arti siap-siap-an mungkin ya. Kebijakan-kebijakan di pendidikan biasanya akan tetap seperti itu. Berbagai terobosan mungkin sudah dilakukan. Tetapi untuk sementara, agaknya kita memang masih seperti ini. Namun sampai kapan? Jika dibiarkan berlarut-larut, tentu akan lepas kendali. Di luar kontrol. Contoh terbaru (Kompas.Com, diakses tgl 9 Pebruari 2021), soal ada seorang kepala sekolah menghimbau agar anak didiknya yang non-muslim untuk mengenakan jilbab walaupun dengan alasan menutup aurat maupun menghalau dingin dan nyamuk tentu kreativitas dan inovasi semacam itu tidak dibenarkan. Demikian pula mereka yang mengenakan jilbab (untuk menutup aurat) diminta melepaskan jilbab jika berada di Papua dan Bali karena tidak sesuai dengan budaya setempat, tentu juga tidak diperkenankan, khususnya sekolah-sekolah milik pemerintah. Kecuali sekolahsekolah yang bukan milik pemerintah, itu soal lain! Kebijakan-kebijakan parsial macam mana pun bebas dilakukan sepanjang tidak menabrak rambu-rambu yang sudah ditetapkan pemerintah. Siswa berambut gondrong, boleh-boleh saja karena sekolah tersebut memang tidak melarangnya.

Kreativitas dan inovasi dari kepala sekolah dan parapengajar tersebut jelas kebablasan dan melampuai batas wewenang. Maksudnya mungkin akan baik-baik saja tetapi tidak melihat sesuatu itu secara jernih dan terbuka serta komprehensif sehingga keberlakuan itu akan mendapatkan penolakan, hujatan, makian dan cemoohan dari berbagai pihak. Barangkali pemerintah, di sini, dalam menjaga kreativitas dan inovasi parapengajar itu pulalah maka kurikulum berskala nasional ditetapkan. Sikap netral pemerintah dan menjaga kekisruhan di dunia pendidikan bisa teratasi. Nampaknya, mungkin hampir sama kalau kita melihat di kepolisian kita. Barangkali jarang kita temui bahwa Kapolda untuk Papua berasal dari mereka yang berkeyakinan muslim (https://id.wikipedia.org/ Kepolisian_Daerah Papua. Diakses tgl 10 Pebruari 2021). Demikian pula untuk Aceh. Tidak akan mungkin kita mendapatkan seorang Kapolda berasal dari mereka yang berkeyakinan non-muslim. Memang hal tersebut sepertinya tidak diatur tetapi kebijakan demikian menyesuaikan dengan kondisi daerah. Dalam bahasa kekinian, itulah yang disebut dengan muatan lokal, tidak tertulis (Lektur.id 2021). Tertulisnya tentu tidak demikian. Semua daerah boleh-boleh saja dijabat oleh siapa pun (kapolda). Soalnya, kalau dipaksakan tentu boleh-boleh juga; toh peraturan pun tidak mengatakan demikian (harus sama). Tetapi, apakah seorang Kapolda tidak mengalami kesulitan jika dalam perjalanannya mendapatkan resistensi/penolakan dari bawahannya; kalau pun menjalankan perintah tetap menjalankan tetapi perintah dimaksud dilaksanakan dengan setengah hati/ogah-ogahan. Tidak usahlah berbicara apa yang mungkin bakal terjadi berikutnya. Pastinya, semua itu tidak dapat berjalan-lancar dan makan hati. Secara struktural kedudukan tersebut jelas paling tinggi di daerah. Tentu seorang Kapolda tidak akan berjalan sendirian tanpa dukungan dari bawahan.

Bentuk lain adalah sikap mental kita sendiri dalam menjalankan aturan kurikulum. Sudah banyak bukti sampai kapan pun agak sulit untuk memberlakuan kurikulum dengan lurus sesuai aturan. Setiap jenjang di daerah-daerah sudah pula ada inspektorat sebagai badan pengawas birokrasi seperti yang dikatakan tadi, tetapi tetap saja sarana dan 
prasarana untuk berjalan baiknya sebuah kurikulum juga tidak mudah. Mungkin kurikulumnya sampai ke daerah-daerah tetapi sarana dan prasarana pendukungnya di daerah-daerah tidak lengkap atau tinggal sedikit karena dipotong di sana-sini dengan alasan macam-macam; sehingga kurikulum memang ada dan tetap berdiri tegar tetapi keropos di dalamnya. Mungkin dari pusat-Jakarta sudah tidak utuh dalam perjalanan sebuah kurikulum. Mungkin contoh di atas, dikementrian KKP dan Sosial menjadi bukti, bagaimana tidak mudah berjalannya sebuah kurikulum. Contoh lain lagi. Sekolah Menengah Kejuruan dengan lebih banyak aspek psikomotoriknya alias prakteknya. Yakinkah kita materi pembelajaran dengan didukung sarana dan prasarana sampai ke daerah-daerah sesuai dengan peruntukkannya? Apalagi di pelosok Pulau Rote sana? Bagaimana dengan inspektorat-nya? Pertanyaan-pertanyaan lain dapat ditambahkan, dan kita akan sulit menjawabnya. Mentalitas korupsi ada di mana-mana. Tidak kurang KPK, inspektorat, semua manusia Indonesia beragama dll; bahwa semua itu sebagai benteng pertahanan untuk mengawasi seseorang agar tidak berbuat menyimpang? Masih ingat tentang pengadaan AlQuran oleh sebuah instansi pemerintah? Pengadaan itu pun tidak luput dari korupsi. Jadi bisa kita bayangkan. Pelakunya seorang muslim. Dari partai yang cukup-besar kok tegateganya sampai meng-korupsi Al-Quran sebagai kitab suci umat muslim. Juga kitab suci umat-umat lain, sama saja di-korupsi. Kan sangat mengerikan bukan!

\section{Simpulan dan Saran}

Berbicara tentang pendidikan di negeri ini, tentu tidak ada habis-habisnya dan beragam upaya mungkin sudah pula dilakukan, namun hasilnya masih seperti itu-itu saja. Hujatan dan cemoohan kepada dunia pendidikan masih terus terjadi. Sebentar-sebentar pendidikan yang disalahkan. Jadi serba salah. Mungkin salah satu penyebabnya karena ketersebaran pulau-pulau di negara kita yang berjauhan satu sama lain, juga diikuti dengan kualitas institusi pendidikan yang kurang memadai. Kedekatan (jarak) dengan pusat-pusat pemerintahan menunjuk pada mereka yang jauh lebih baik daripada mereka yang berada di pelosok daerah dan pulau-pulau terpencil. Belum lagi sarana dan prasarana yang kurang sesuai dengan peruntukannya, semakin memperlebar dan bertambah rumit. Dalam kondisi demikian, siapa pun menteri pendidikan dan kebudayaannya, menjadi tidak mudah untuk dilakukan. Apalagi menterinya hanya duduk-duduk saja disinggasananya sebagai menteri, tentu makin merepotkan dan asing dengan pekerjaannya. Mengandalkan berjalannya birokrasi, selain lama dan berbelit-belit juga pemotongan di sana-sini merupakan 'kegiatan tambahan' yang masuk dalam kebijakan-kebijakan. Pembentukan KPK yang ada di pusat pemerintahan; yang dulunya ada inspektorat (sekarang pun masih) untuk mengawasi pembangunan tetap saja terjadi penyimpangan. Kita tidak mau berbicara soal Mensos maupun Men-KKP yang pejabatnya terlibat korup ini (Investor Daily. Diakses tanggal 8 Desember 2020). Jika berani, untuk tidak memilih-memilah maka hampir di semua jenjang daerah akan mengalami kasus serupa. KPK itu hanya berada di Jakarta, bagaimana dengan mereka yang berada di daerah? Ini persoalan mental-budaya masyarakat kita.

Oleh karena itu, untuk menghindari hal seperti itu, siapa yang berani menjamin jika kurikulum pendidikan akan sama persis dengan pusat-pusat pemerintahan di daerah maupun pusat-Jakarta? Tidak ada bukan!. Tentu, kita sangat berharap dengan adanya 
loyalitas, tanggung-jawab dan kesetiaan sebagai pengajar dapat menjadi mercu-suarnya. Tidak banyak orang yang besedia dengan sepenuh hati mengabdikan diri kepada profesi guru/dosen yang mulia ini. Orang hanya bisa berbicara tentang kemuliaan, kesetiaan dan pengabdian tetapi kalau seseorang itu diminta untuk memilih maka profesi sebagai parapengajar bukanlah sebagai urutan pertama, kecuali jika orangtua mereka sebagai pendidik, itu persoalan lain. Soalnya, hampir dipastikan sang anak akan menjadi jadi pengajar pula. Lebih-lebih dalam dua dasawarsa terakhir semakin sulit menemukan orang yang memilih pekerjaan sebagai pengajar dalam kehidupannya. Apa yang kita lihat dan saksikan pada saat rekrumen ASN misalnya, tidak lebih sebagai upaya untuk menghindar (agar tidak dilabelkan) sebagai penganggur alias tidak bekerja. Umumnya, mereka yang lebih cerdas memang dengan sangat mudah melewati tes-tes, ASN misalnya, ketimbang orang yang penuh dedikasi, tanggung-jawab dan memilih profesi parapengajar. Tapi jika tes-tes diberi muatan lokal, dalam satu-dua hari tidak mungkin akan dapat dicerna muatan lokal tersebut. Perlu diadakan muatan lokal tersebut agar diskriminasi positif itulah yang terjadi. Jadi, paling tidak, orang datang dari Jawa tidak terlalu berminat memilih Luar Jawa sebagai pilihannya, meski di Jawa dia sebagai penganggur.

\section{Daftar Rujukan}

Fathoni, Baharuddin. (2020). Pedagogi Reflektif Sebagai Pembelajaran Humanis. Historika, volume 23(1): 79-91.

Hadi, Mohammad. (2021). Sistem Penyelenggaraan Pendidikan Guru Berkualitas Dikementerian Agama. https: ejournal.iainkendari.ac.id. Diakses tgl 22 April 2021.

Hartanto, Irfan Guntara (2017). Ketersediaan Sarana dan Prasarana Pendidikan dalam Program Kelas Khusus Olahraga (KKO) Sekolah Olahraga Menengah Atas Negeri I Sewon Kabupaten Bantul. Jurnal Hanata Widya, volume 6(7): 10-20.

Huda, Mohammad Nurul (2018).Optimalisasi Sarana dan Prasarana dalam Meningkatkan Prestasi Belajar Siswa.Jurnal Manajemen Pendidikan Islam, volume 6(2): 51-69.

Https://id.wikipedia.org/wiki/Kepolisian_Daerah_Papua. Diakses tanggal 10 Pebruari 2021.

Investor Daily. Korupsi Mensos dan Korupsi Men-KKP: Ideological Corruption. Diakses tanggal 8 Desember 2020.

Kasirah, Ira (2014). Kompetensi Pedagogis Guru PLB dalam Meningkatkan Pretasi Belajar Anak Berkebutuhan Khusus. Jurnal Perspektif Ilmu Pendidikan, volume 24.

Killian, P.M, E (2012). Paradigma Problematika Diplomasi Ekonomi Indonesia. Jurnal Global dan Strategi, volume 6(2): 170-185.

Kompas.Com (23 Januari 2021). Alasan Siswi Non-Muslim Diwajibkan Pakai Jilbab, Mantan Wali Kota Padang: Itu kearifan Lokal. Diakses tanggal 9 Pebruari 2021.

Kurjono, Badria Muntashofi. (2021). Pengaruh Kompetensi Dosen Terhadap Motivasi Belajar Mahasiswa (Survei Pada Mahasiswa Angkatan 2012 Kelas B Program Studi Pendidikan Akutansi UPI). JPAK: Jurnal Pendidikan Akuntansi dan Keuangan, volume 3(1): 1-12.

Lektur.id (2021). Arti 'Muatan lokal' di Kamus Besar Bahasa Indonesia (KBBI). Diakses tanggal 22 April 2021.

Nurhadi (2018). Paradigma Ideologi Sistem Ekonomi Dunia. Jurnal Ilmiah Keislaman, volume 17(1): 97-129. 
Nugraheni, S (1997).Pedagogi Internasional dn Lingkungan Hidup: Kasus Negara Sedang Berkembang. Jurnal Bina Ekonomi: 10-17.

Lia, Kurniawati; Siti Nurrochmah; Septa Katmawanti (2017).Hubungan Antara Tingkat Pendidikan, Status Pekerjaan dan Tingkat Pendapatan dengan Usia Perkawinan Pertama di Kelurahan Kotalama Kecamatan Kedungkandang Kota Malang. Jurnal Prevensia, volume 2(1): 210-219.

Utami, Sri (2009). Peningkatan Mutu Pendidikan Indonesia Melalui Peningkatan Kualitas Personel, Profesional, Dan Strategi Rekrutmen Guru. Prosiding Seminar Nasional Pendidikan FKIP, volume 2(1): 518-527.

Puspaningrum, Nofemi; Catur Styorini (2014). Hubungan Antara Tingkat Pendidikan Formal Dengan Pengetahuan Ibu Hamil Tentang Perawatan Bayi Baru Lahir di Kalurahan Suruhkalang Kecamatan Janten Kabupatan Karanganyar 2013. Jurnal Kebidanan Indonesia, volume 5(2): 135-148.

Seran, Sirius (2017). Hubungan Antara Pendidikan, Pengangguran Dan Pertumbuhan Ekonomi Dengan Kemiskinan. Jurnal Ekonomi Kuantitatif Terapan, volume 10(1): $59-71$.

Widyaningrum, Heny, Kusuma (2021). Pentingnya Strategi Pembelajaran Inovatif dalam Menghadapi Kreativitas Siswa di Masa Depan. Prosiding.unipma.ac.id. Diakses tanggal 22 April 2021.

Yasir, S. Nor, Hasanah (2018). Manajemen Peningkatan Kualitas Dosen (Studi Kasus Pada Fakultas Tarbiyah UI Malang). Journal of Research and Thought of Islamic Education, volume I(1): 96-107. 